\title{
해양경찰공무원의 조직내 신뢰와 조직몰입과의 관계 The Relationship between Trust and Organization Commitment within Organization of Coast Guard Officers
}

\author{
유영현
}

대불대 경찰행정학과

\author{
Yung-Hyun Yu(hyun1495@yahoo.co.kr)
}

\section{요약}

해양경찰조직은 해양경찰공무원들의 조직 신뢰 및 대인간 신뢰가 바탕을 이뤘을때 조직의 효과성이 크게 고양될 것으로 기대된다. 해양경찰조직은 해상에서 함정을 근무수단으로 하여 각종 해상치안서비스를 담당 하고 있다. 해양경찰공무원들의 경우 조직내 신뢰요인들별로 조직몰입에 미치는 양상을 조사함으로서 향후 해양경찰공무원들의 조직몰입도 제고노력이 요구되어진다. 이에 대한 실증적 연구를 행한 결과 핵심 내용 은 다음과 같다.

해양경찰공무원의 경우 조직신뢰요인은 조직몰입에 가장 강한 영향력을 미치고 있다는 것을 알수 있었고 다음으로 대인간 신뢰요인중에서는 동료신뢰 요인이 상관신뢰 요인보다 상대적으로 더 많은 영향력을 미치 고 있다는 것을 알 수 있었다. 다음으로, 해양경찰공무원의 인구사회학적 특성에 따른 신뢰요인 인식의 차 이를 살펴보면, 비 간부에 비해 간부가 동료를 더욱 신뢰하고 있다는 것을 알 수 있다. 상관신뢰보다 동료에 대한 신뢰가 높은 이유는 해양경찰의 경우 근무여건으로 인하여 그들간의 접촉 빈도가 많은 것으로 보여진다.

이 연구결과 해양경찰공무원의 조직몰입도 제고를 위해서는 조직신뢰와 동료신뢰를 제고시키는 다양한 인사 · 조직 관리전략이 필요로 되어짐을 발견할 수 있다.

- 중심어 : |신뢰|조직몰입|해양경찰|

\section{Abstract}

Coast guard organization has very different working environment with other general administrative organizations or police organizations. Because they are charging various coastal crimes and safeties by using war vessel at ocean, it was expected that in case of coast guard officers, the impact on organization commitment for each trust factor within organization has the differentiation with other administrative organizations. Core of results by conducting positive research is as following:

It is indicated that for coast guard officer, organization trust factor most strongly impacts on organization commitment, and of social trust factors, colleague trust factor more impacts relatively than boss trust factor. Then, when searching the difference of trust factor recognition depending on population sociological properties of coast guard officers, it is indicated that the one having the experience of working at war vessel has more trust to its colleagues than the one having not and executives more trust their boss than non-executives. The reason why the trust to colleague is higher than to boss is recognized that it is caused from deep relationship with colleagues who work and live together when considering working conditions of security vessel.

- keyword: |Trust|Organization Commitment|Coast Guard|

접수번호 : \#091103-001

접수일자 : 2009년 11월 03일
심사완료일 : 2009년 12월 22일

교신저자 : 유영현, e-mail : hyun1495@yahoo.co.kr 


\section{I. 서론}

종래 대량생산시대를 주도해 온 조직관리전략은 불 신이나 저신뢰를 바탕으로 한 통제위주의 방식이었지 만, 앞으로 요구되는 21세기형 조직관리방식은 신뢰를 기본으로 한 조직몰입중심의 전략이 되어야한다. 종래 통제지향적 관리전략의 산물인 무사안일, 자기제한 적 - 자기방어적 행태와는 달리 조직과 개인의 일체감 으로부터 우러나는 조직몰입이 전제되어야 한다, 구성 원들의 조직몰입을 기대하려면 먼저 그들에게 권한과 재량권과 자율을 주어야 하며, 이것은 구성원에 대한 조직의 신뢰로부터 시작된다. 신뢰를 바탕으로 하지 않 은 분권화와 재량은 진정한 것이라고 볼 수 없으며 조 직몰입에 기여하기 어렵다[1].

해양경찰은 해양이라는 특수한 근무환경 속에서 해 상경비활동, 해상범죄단속, 해상수색 및 구조 활동 등의 업무를 엄격한 상명하복관계의 계급구조하에서 전통적 으로 통제지향적 관리를 위주로 하여 왔다. 그러나 해 양경찰공무원들이 통제관리대상에서 다소나마 탈피하 여 신뢰를 바탕으로 민주적-개방적으로 조직관리 됨 으로서 조직에 몰입되어지게 한다면 신속하고 자발적 으로 해상에서의 치안행정 서비스가 이뤄질 것이며 궁 극적으로는 국민으로부터 신뢰 받는 해양경찰이 될 것 이다. 그러나 선행연구물들을 검토한 결과 그동안 해양 경찰의 조직 내 신뢰 문제 와 조직몰입과의 관계를 연 구한 연구물들은 전무하다. 따라서 본 연구에서는 해양 경찰공무원을 대상으로 조직내 신뢰와 조직몰입의 관 계를 실증적으로 검토하여 해양경찰공무원의 조직몰입 도 제고를 위한 해양경찰인사관리정책을 수립하는데 시사점을 제공하고자한다.

\section{II. 이론적 논의}

\section{1. 신뢰와 조직몰입의 의의}

신뢰는 상대가 기꺼이 자신의 기대에 부응하여 행동 할 것이라는 믿음을 의미하여 신뢰는 그자체로서 우수 한 통제장치로 기능하며, 경제적비용을 절감시키는 효
율적인 조직관리 수단이 된다고 보고있다. 박준철 (2007)은 조직 내에서 상하급자 간에 협동을 도출하는 데는 통제에 의한 방법과 신뢰에 의한 방법이 있다고 주장한다. 통제적 방식은 협력을 의무화하고 이를 어길 경우 처벌을 가능케 하는 각종 관리수단을 도입하는 것 이며, 신뢰적 방식은 교환과정에 별도의 감시자가 통제 장치를 두지 않고 상하급자 간에 형성되는 믿음에 근거 하여 자유의사에 맡길 수 있다. 이 점에서 신뢰적 방식 은 통제적 방식에 비하여 효율적 관리수단이 된다[2]. 신뢰의 개념에 대해 학자들 간의 합의된 개념은 없지 만 최근 들어 자주 인용되는 신뢰의 개념은 "자신이 상 대방을 감시하고 통제할 수 없더라도, 자신에게 중대한 행동을 상대방이 할 것이라는 기대를 바탕으로 상대방 의 행동에 대해 자신을 취약한 상태에 두려는 자발성 (willingness to vulnerable)" 이다[3]. Kramer(1996)는 신뢰의 중요성과 신뢰의 문제점들은 최소한 부분적으 로 상호 취약성(vulnerabilities)과 계층제적 관계에 내 재하고 있는 불확실성으로부터 시작된다고한다[4]. Griffin(1967)은 신뢰란 위험한 상황 하에서 불확실한 목적을 성취하기 위하여 어떤 구성원의 행태에 대한 믿 음으로 간주되며, 조직몰입에도 영향을 미칠것이다[5]. 조직몰입은 한 조직의 가치, 규범에 대해 개인이 느끼 는 동일화의 정도와 이를 실현시키는 자발적 의지라고 할 수 있다[6]. 일반적으로 조직몰입에 대한 정의들은 조직에 대한 충성심(loyalty), 조직의 목표 달성을 위한 자발적인 노력(willingness). 조직이 추구하는 목표나 가치에 대한 강한 신뢰와 수용(identification), 조직에 남아 있으려는 강한 욕구( attachment) 등을 포함하고 있다[7]. 조직구성원의 신뢰를 바탕으로 한 행동이 조직 몰입의 강화를 초래한다. 조직구성원이 신뢰, 권위를 인 정함으로써 조직에 대한 동일감이 유발되어 조직몰입 도가 제고된다. 신뢰를 통한 조직몰입의 강화는 조직의 일체감형성에 주요 요인이 된다[8]. 또한 신뢰는 조직구 성원간의 직무업무 및 성과를 강화시킴은 물론 조직구 성원간의 업무와 정보, 조직구성원간 다양하고 폭 넓은 지식과 기술의 공유를 가능하게 해준다. 


\section{2. 신뢰의 유형}

조직 내 신뢰의 양상은 동료들 상호간의 수평적 신뢰 와 부하와 상관간, 구성원과 조직(혹은 최고관리자)간 의 수직적 신뢰로 구분할 수 있다[9]. 동료는 신뢰하지 만 상관이나 조직은 신뢰하지 않을 수 있으며, 상관과 조직에 대한 신뢰의 정도도 서로 다를 수 있으므로 이 세 가지 유형의 신뢰는 상이한 차원(하위변수)으로 취 급될 수 있다.

\section{3. 신뢰와 조직몰입간의 관계와 선행연구}

경찰공무원을 대상으로 한 최근의 조직몰입에 관한 연구들은 장석헌(2007), 주재진(2008), 송병호(2005), 이 창한(2006), 김구(2005)등이 있으나 경찰공무원들의 조 직내 신뢰와 조직몰입과의관계를 다루 연구는 전무하 다[10-14]. 또한 해양경찰공무원을 대상으로한 조직몰 입에관한 연구도 전무한 편이다.

선행연구상의 조직신뢰, 대인신뢰와 조직몰입과의 관계를 보면, Cook Wall(1980)은 조직신뢰와 상사신뢰 각각의 변수와 조직몰입과의 상관분석결과 조직신뢰와 상사신뢰와의 상관관계가 상대적으로 강하게 나타났다 고 분석했다[15]. 김석용(2005), Roberts 와 O'Reilly(1974)등은 상사신뢰와 조직 몰입간에는 유의 미한 상관관계가 존재한다고 말했고[16][17] DeCotiis \& Summers (1987)는 조직신뢰는 조직몰입과 상대적 으로 강한 상관성을 보인다고 강조했다[18]. 한편, Hrebiniak \& Alutto(1972), Blake \& Mouton (1984)은 상사에 대한 부하의 신뢰 정도는 조직몰입에 긍정적인 영향을 미친다고 지적했다[19][20]. Tan \& Tan(2000) 은 미국의 회사원을 대상으로 실시한 상사신뢰와 조직 신뢰의 차이에 대한 연구에서 상사신뢰는 혁신적 행태 에 정 $(+)$ 의 영향을 미쳤고 조직신뢰는 조직몰입에 강한 정 $(+)$ 의 영향을 미친다고 말했다[21]. 한편, 공공조직을 대상으로 조직신뢰와 조직몰입과의 관계에 대한 국내 의 주요연구를 보면 김호정(1999)과 박철민·김대원 (2003)의 연구가 있다[22]. 김호정(1999)은 신뢰와 조직 몰입과의 관계에 대해 공무원(중앙부처와 지방기초자 치단체 등)과 회사원(대기업, 중소기업)을 대상으로 경 험적 연구를 진행하였다. 그의 연구결과에 의하면 조직
내 신뢰인 조직신뢰, 상관신뢰, 동료신뢰 3 가지 중 조직 신뢰가 조직몰입에 상대적으로 유의미한 정 $(+)$ 의 영향 을 미쳤다는 것이다. 또한 상관신뢰가 동료신뢰에 비해 조직몰입에 상대적으로 높은 상관성을 가진다고 분석 했다. 정찬수(2005)는 문화관광부의 구성원들은 조직신 뢰가 대인신뢰보다 조직몰입에 더강한 영향을 미치며 이중 부하신뢰요인도 조직몰입에 정의 영향을 미치고 있음을 알수 있다[23]. 이러한 결과는 서울시정개발 연 구원 (2002)의 연구결과와도 동일하다[24]. 선행연구들 중 공공행정조직을 대상으로 한 연구들은 매우 제한적 이었으나, 신뢰와 조직몰입과의 인과관계가 정 $(+)$ 의 방 향성을 가질 수 있음을 시사해주고 있다고 판단한다. 이 같은 연구결과들을 토대로 다음과 같은 연구 모형과 연구 가설을 설정하고자 한다.

\section{III. 연구 설계}

\section{1. 연구 분석의 틀 및 가설}

신뢰와 조직몰입과의 관계에 대한 이론적 논의에서 와 같이 조직신뢰, 상사신뢰, 동료신뢰는 조직몰입에 긍 정적 영향을 주는 것으로 밝혀졌다. 따라서 본 연구는 해양경찰의 조직내 신뢰(조직신뢰, 대인간 신뢰)가 조 직몰입에 미치는 영향을 규명하고자 하였다. 그간 해양 경찰의 조직신뢰 및 대인간신뢰에 대한 연구가 거의 부 재한 상태에서 본 연구는 조직신뢰와 대인간 신뢰가 조 직몰입에 얼마만큼의 영향력을 미치는지를 살펴 향후 해양경찰공무원의 조직몰입도를 제고하는 시사점을 제 공키로 하였다. 구체적으로 조직신뢰와 대인간신뢰(상 관신뢰, 동료신뢰)를 독립변수로 하였고, 조직몰입을 종속변수로 하여 연구를 설계하였다. 또한 해양경찰공 무원중 함정근무경력자와 무경력자간 그리고 간부와 비간부간에 각 신뢰양상별로 조직몰입에 미치는 영향 에 차이가 있을 것으로 예상되어 다음 [그림 1]과 같은 연구 모형과 가설을 제시하였다. 


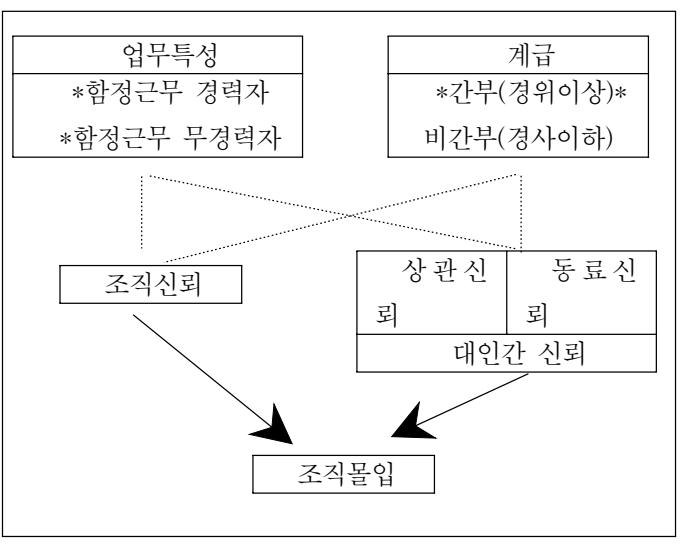

그림 1. 연구 분석의 틀

본 연구의 가설은 다음과 같이 설계 하였다. 즉, 해양 경찰공무원의 신뢰 수준(조직 신뢰, 상관 신뢰, 동료 신 뢰)은 조직 몰입에 긍정적인 영향을 미칠 것이라는 가 설과 함께 해양경찰공무원의 인구사회학적 특성(함정 근무 여부, 계급 등)에 따라 조직 신뢰, 상관 신뢰 및 동 료 신뢰에 유의미한 차이가 있을 것이라는 가설을 설정 하였다.

가설 I. 해양경찰공무원의 신뢰 수준(조직 신뢰, 상 관 신뢰, 동료 신뢰)은 조직 몰입에 긍정적 인 영향을 미칠 것이다.

가설 ㅍ. 해양경찰공무원의 인구사회학적 특성(함정 근무 여부, 계급 등)에 따라 조직 신뢰, 상관 신뢰 및 동료 신뢰에 유의미한 차이가 있을 것이다.

\section{2. 변수외 조작적 정의 및 측정}

본 연구에서 선정된 세 가지 신뢰와 조직몰입을 측정 하기 위해 조직신뢰와 동료신뢰는 Cook \& Wall(1980) 의 척도로 측정했고, 상관신뢰는 Podsakoff 외(1990)의 척도를 이용했다[25]. 이들 척도는 신뢰의 대표적 속성 인 '진실성', ‘온정' ‘능력'을 고루 포함하는 것으로, 조직 신뢰는 배려(온정), 정직 · 공정(진실성), 능력을 측정 하고, 동료신뢰는 지원(온정), 정직(진실성), 능력을 물 었으며, 상관신뢰는 공정 - 정직(진실성), 충성 - 지 원(온정)을 주요 내용으로 하고 있다. 또한 조직몰입은 조직동일화, 조직애착, 직무몰두(노력)의 내용을 모두
포함하고 있는 김호정(1999)의 척도로 측정하였다. 각 변수의 문항들은 Likert-type의 5 점 척도로 구성 하였다.

\section{3. 자료의 수집 및 분석방법}

연구결과의 대표성을 높이기 위해 해양경찰청 산하 3 개 지방청(동해, 서해, 남해)을 포괄하여 각 지방청 산 하 우리나라 전역에 해양경찰서(군산, 동해, 목포, 부산, 서귀포, 속초, 여수 완도, 인천시, 제주, 태안, 통영, 포 함) 및 해양경창청 직속기관인 정비창과 해양경찰학교 등에 근무중인 해양경찰청 직속기관인 정비창과 해양 경찰학교 등에 근무중인 해양경찰공무원들을 설문대상 으로 하였으며 2009년 8월 1일부터 2009년 8월 31일 까 지 한달 간에 걸쳐 최종적으로 300 부의 설문지를 회수 하였다.

본 연구는 자료 수집을 위해 표준화된 설문지를 이용 하였으며, 측정은 Likert의 5점 척도(매우 부정 - 1점, 부정 - 2점, 보통 - 3 점, 긍정 - 4 점, 매우 긍정 - 5점)방 식으로 등간 척도로 구성하였다. 본 연구에서 분석을 위한 설문지 분석은 통계패키지 SPSS Win 15.0을 이 용하였다. 인구통계 변수를 정리하기 위하여 빈도분석 (Frequency Analysis)을 실시하였으며, 각 요인에 대한 설문문항의 구성타당도 및 내적 일관성을 조사하기 위 하여 요인분석(Factor Analysis) 및 신뢰도 검증 (Reliability Test)을 실시하였다. 또한, 신뢰가 조직몰 입에 미치는 영향관계 등을 살펴보고, 인구사회학적 특 성에 따른 차이를 살펴보기 위하여 다음과 같이 상관관 계분석, 회귀분석, $\mathrm{T}$-검증 및 분산분석을 실시하였다.

\section{4. 측정도구의 신뢰도}

일반적으로 신뢰도 분석에 있어서 Cronbach's a 계 수가 0.7 이상이면 강한 응집력을 갖는다고 할 수 있고, 0.3 이하면 약하다고 할 수 있으며 그 중간이면 보통이 라고 할 수 있다. 이에 따라 설문문항의 신뢰도를 검증 하기 위하여 요인분석을 실시하여 각 요인별로 항목을 묵은 후 내적 일관성을 조사하는 Cronbach's a를 값을 구한 결과는 다음 [표 1]과 같이 대부분의 요인이 0.8 이 상으로 나타나 설문문항의 일관성이 어느 정도 확보되 었다고 할 수 있다. 
표 1. 요인별 신뢰도 측정 결과

\begin{tabular}{|c|c|c|}
\hline \multicolumn{2}{|c|}{ 변수 / 요인 } & $\begin{array}{c}\text { Cronbach's } \\
\text { alpha(N) }\end{array}$ \\
\hline \multirow{3}{*}{ 신뢰 } & 조직 신뢰 & $0.8552(\mathrm{~N}=300)$ \\
\cline { 2 - 3 } & 상관 신뢰 & $0.8994(\mathrm{~N}=300)$ \\
\cline { 2 - 3 } & 동료 신뢰 & $0.8605(\mathrm{~N}=300)$ \\
\hline 조직 몰입 & 조직 몰입 & $0.8716(\mathrm{~N}=300)$ \\
\hline
\end{tabular}

\section{5. 조사대상자의 일반적 특성}

본 연구의 조사대상자의 인구통계학적 특성을 살펴 보면 다음 [표 2]와 같다.

\section{표 2. 조사대상자의 일반적 특성}

\begin{tabular}{|c|c|c|c|}
\hline \multicolumn{2}{|c|}{ 구분 } & 빈도 & 퍼센트 \\
\hline \multirow{3}{*}{ 성별 } & 남자 & 275 & 91.7 \\
\hline & 여자 & 25 & 8.3 \\
\hline & 합계 & 300 & 100.0 \\
\hline \multirow{5}{*}{ 연령 } & 20대 & 41 & 13.7 \\
\hline & 30대 & 173 & 57.7 \\
\hline & 40대 & 71 & 23.7 \\
\hline & 50대 & 15 & 5.0 \\
\hline & 합계 & 300 & 100.0 \\
\hline \multirow{5}{*}{ 학력 } & 고졸이하 & 49 & 16.3 \\
\hline & 전문대졸 & 54 & 18.0 \\
\hline & 대졸 & 188 & 62.7 \\
\hline & 대학원졸 이상 & 9 & 3.0 \\
\hline & 합계 & 300 & 100.0 \\
\hline \multirow{8}{*}{ 근무년수 } & 5년 이하 & 132 & 44.0 \\
\hline & 5-10년 & 67 & 22.3 \\
\hline & 11-15년 & 57 & 19.0 \\
\hline & 16-20년 & 24 & 8.0 \\
\hline & 21-25년 & 15 & 5.0 \\
\hline & 26-30년 & 3 & 1.0 \\
\hline & 31년 이상 & 2 & .7 \\
\hline & 합계 & 300 & 100.0 \\
\hline \multirow{7}{*}{ 계급 } & 순경 & 74 & 24.7 \\
\hline & 경장 & 92 & 30.7 \\
\hline & 경사 & 81 & 27.0 \\
\hline & 경위 & 46 & 15.3 \\
\hline & 경감 & 5 & 1.7 \\
\hline & 경정 & 2 & .7 \\
\hline & 합계 & 300 & 100.0 \\
\hline
\end{tabular}

\section{IV. 분석 결과}

\section{1. 신뢰에 대한 요인분석 결과}

신뢰에 대한 요인분석을 실시한 결과 다음 [표 3]과 같이 3 개의 요인으로 요인이 추출되었다. 요인추출 방 법은 주성분 분석 이후 Kaiser 정규화가 있는 Varimax 회전방식에 의해 회전을 실시하여 요인적재값을 산출 하였다. 요인은 조직 신뢰, 상관 신뢰, 동료 신뢰로 추출 되었다.

\section{표 3. 신뢰에 대한 요인분석 결과}

\begin{tabular}{|c|c|c|c|}
\hline \multirow[b]{2}{*}{ 구분 } & \multicolumn{3}{|c|}{ 성분 } \\
\hline & $\begin{array}{c}\text { 조직신뢰 } \\
\text { 요인 } \\
\text { (성분 3) }\end{array}$ & $\begin{array}{c}\text { 상관신뢰 } \\
\text { 요인 } \\
\text { (성분 1) }\end{array}$ & $\begin{array}{c}\text { 동료신뢰 } \\
\text { 요인 } \\
\text { (성분 2) }\end{array}$ \\
\hline$\times 01$ & .838 & .170 & .165 \\
\hline$\times 02$ & .793 & .386 & .193 \\
\hline$\times 03$ & .708 & .168 & .261 \\
\hline$\times 04$ & .728 & .297 & .202 \\
\hline$\times 05$ & .270 & .735 & .315 \\
\hline$\times 06$ & .132 & .717 & .173 \\
\hline$\times 07$ & .235 & .856 & .216 \\
\hline$\times 08$ & .349 & .757 & .275 \\
\hline$\times 09$ & .327 & .722 & .372 \\
\hline$\times 10$ & .252 & .195 & .830 \\
\hline$\times 11$ & .174 & .131 & .855 \\
\hline$\times 12$ & .163 & .317 & .751 \\
\hline$\times 13$ & .234 & .308 & .670 \\
\hline$\times 14$ & .152 & .263 & .688 \\
\hline \multirow{2}{*}{ 성분 } & \multicolumn{3}{|c|}{ 회전 적재값 } \\
\hline & 합계 & 분산 & 누적 \\
\hline 1 & 3.493 & 24.951 & 24.951 \\
\hline 2 & 3.469 & 24.781 & 49.732 \\
\hline 3 & 2.935 & 20.964 & 70.696 \\
\hline
\end{tabular}

요인추출 방법: 주성분 분석.

회전 방법: Kaiser 정규화가 있는 베리멕스.

\section{2. 신뢰 요인과 조직몰입간의 회귀분석 결과}

신뢰 요인과 조직몰입간의 영향관계를 살펴보기 위 하여 다중회귀분석을 실시한 결과 다음 [표 4]와 같이, 유의확률 $(\mathrm{P}<0.01)$ 을 살펴보면, 조직신뢰 요인(B: 0.542, $\beta: 0.567)$ 과 대인간 신뢰 요인(B: 0.388, $\beta$ : 0.320)이 각 각 조직몰입에 정(+)의 영향력을 미치고 있다는 것을 알 수 있다. 
표 4. 신뢰 수준과 조직몰입간의 다중회귀분석 결과

\begin{tabular}{|c|c|c|c|c|c|c|c|}
\hline \multirow{2}{*}{ 구분 } & \multicolumn{2}{|c|}{$\begin{array}{l}\text { 비표준화 } \\
\text { 계수 }\end{array}$} & \multirow{2}{*}{ 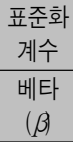 } & & \multirow{2}{*}{$\begin{array}{l}\text { 유의 } \\
\text { 확률 }\end{array}$} & \multicolumn{2}{|c|}{ 공선성 통계량 } \\
\hline & B & $\begin{array}{l}\text { 표준 } \\
\text { 오차 }\end{array}$ & & & & $\begin{array}{c}\text { 공차한 } \\
\text { 계 }\end{array}$ & VIF \\
\hline (상수) & .290 & .157 & & 1.849 & .065 & & \\
\hline $\begin{array}{l}\text { 조직 } \\
\text { 신뢰 }\end{array}$ & .542 & .043 & .567 & 12.693 & $.000^{* *}$ & .574 & 1.741 \\
\hline $\begin{array}{l}\text { 대인 } \\
\text { 신뢰 } \\
\end{array}$ & .388 & .054 & .320 & 7.159 & $.000^{* *}$ & .574 & 1.741 \\
\hline
\end{tabular}

종속변수 : 조직몰입/ ${ }^{*} \mathrm{p}<0.05,{ }^{* *} \mathrm{p}<0.01$

구체적으로 신뢰 하위 요인과 조직몰입간의 영향관 계를 살펴보기 위하여 다중회귀분석을 실시한 결과 다 음 표5와 같이, 유의확률 $(\mathrm{P}<0.05)$ 을 살펴보면, 조직신뢰 요인(B: 0.552, $\beta$ : 0.578)은 조직몰입에 강한 영향력을 미치고 있다는 것을 알 수 있다. 이러한 결과는 정찬수 (2005), 김호균(2007)의 연구결과와도 일치한다[26]. 조 직내 신뢰와 조직몰입과의 선행연구들은 조직신뢰, 대 인신뢰요인들중 조직신뢰가 조직몰입과의 상관관계가 가장 높게 나타났다. 또한 Cook \& Wall, (1980)의 주장 과도 궤를 같이한다. 다음으로 대인간신뢰 요인 중에서 는 동료신뢰 요인(B: 0.314, $\beta$ : 0.251)이 상관신뢰 요인 (B: 0.09735, $\beta: 0.100$ )보다 상대적으로 더 많은 영향력 을 미치고 있다는 것을 알 수 있다. 즉, 해양경찰의 경 우 조직에 대한 신뢰가 높을수록 조직몰입에 긍정적이 라는 것을 알 수 있다. 또한 상관에 대한 신뢰보다는 동 료에 대한 신뢰가 높을수록 조직몰입에 정적인 영향을 미친다는 것을 알 수 있다. 이러한 이유는 황호영(2005) 의 연구에서와 같이 함정근무자들의 경우 동료간의 접 촉빈도가 많은 것에서 비롯되어지는 것으로 추론해볼 수 있다[27].

표 5. 신뢰 하위 수준과 조직몰입간의 다중회귀분석 결과

\begin{tabular}{|c|c|c|c|c|c|c|c|}
\hline \multirow{2}{*}{ 구분 } & \multicolumn{2}{|c|}{$\begin{array}{c}\text { 비표준화 } \\
\text { 계수 }\end{array}$} & \multirow{2}{*}{$\begin{array}{c}\text { 표준화 } \\
\text { 계수 } \\
\text { 베타 } \\
(\beta)\end{array}$} & \multirow[b]{2}{*}{$t$} & \multirow{2}{*}{$\begin{array}{l}\text { 유의 } \\
\text { 확률 }\end{array}$} & \multicolumn{2}{|c|}{$\begin{array}{l}\text { 공선성 } \\
\text { 통계량 }\end{array}$} \\
\hline & B & $\begin{array}{l}\text { 표준 } \\
\text { 오차 }\end{array}$ & & & & $\begin{array}{l}\text { 공차 } \\
\text { 한계 }\end{array}$ & VIF \\
\hline (상수) & .150 & .166 & & .908 & .365 & & \\
\hline $\begin{array}{l}\text { 조직 } \\
\text { 신뢰 }\end{array}$ & .552 & .043 & .578 & 12.988 & $.000^{* *}$ & .568 & 1.759 \\
\hline $\begin{array}{l}\text { 상관 } \\
\text { 신뢰 }\end{array}$ & 9.735 & .047 & .100 & 2.056 & $.041^{*}$ & .481 & 2.081 \\
\hline $\begin{array}{l}\text { 동료 } \\
\text { 신뢰 }\end{array}$ & .314 & .055 & .251 & 5.672 & $.000^{* *}$ & .573 & 1.746 \\
\hline
\end{tabular}

종속변수 : 조직몰입/ ${ }^{*} \mathrm{p}<0.05,{ }^{* *} \mathrm{p}<0.01$

\section{3. 함정근무 및 계급에 따른 차이분석 결과}

함정 근무 유무에 따른 신뢰(조직 신뢰, 상관 신뢰, 동료 신뢰) 요인 인식에 대한 차이를 살펴보기 위하여 $\mathrm{t}$-검증을 실시한 결과, 다음 [표 6]과 같이 유의미한 차 이가 없는 것으로 결과가 나타났다.

표 6. 함정 근무 유무에 따른 신뢰 수준 인식 차이

\begin{tabular}{|c|c|c|c|c|c|}
\hline \multicolumn{2}{|c|}{ 구분 } & $\mathrm{N}$ & 평균 & $t$ & $\begin{array}{l}\text { 유의 } \\
\text { 확률 }\end{array}$ \\
\hline \multirow{2}{*}{ 조직 } & $\begin{array}{l}\text { 함정 근무 } \\
\text { 유경험자 }\end{array}$ & 225 & 3.3367 & \multirow{2}{*}{0.254} & \multirow{2}{*}{0.799} \\
\hline & $\begin{array}{l}\text { 함정 근무 } \\
\text { 無경험자 }\end{array}$ & 75 & 3.3100 & & \\
\hline \multirow{2}{*}{$\begin{array}{l}\text { 상관 } \\
\text { 신뢰 }\end{array}$} & $\begin{array}{l}\text { 함정 근무 } \\
\text { 유경험자 }\end{array}$ & 225 & 3.6924 & \multirow{2}{*}{-0.035} & \multirow{2}{*}{0.972} \\
\hline & $\begin{array}{l}\text { 함정 근무 } \\
\text { 無경험자 }\end{array}$ & 75 & 3.6960 & & \\
\hline \multirow{2}{*}{$\begin{array}{l}\text { 동료 } \\
\text { 신뢰 }\end{array}$} & $\begin{array}{l}\text { 함정 근무 } \\
\text { 유경험자 }\end{array}$ & 225 & 3.8640 & \multirow{2}{*}{1.336} & \multirow{2}{*}{0.183} \\
\hline & $\begin{array}{l}\text { 함정 근무 } \\
\text { 無경험자 }\end{array}$ & 75 & 3.7573 & & \\
\hline
\end{tabular}

${ }^{*} p<0.05,{ }^{* *} p<0.01$

간부와 비간부 유무에 따른 신뢰(조직 신뢰, 상관 신 뢰, 동료 신뢰) 요인 인식에 대한 차이를 살펴보기 위하 여 t-검증을 실시한 결과, 다음 [표 7]과 같이 동료신뢰 요인에서만 유의미한 차이를 보이고 있다는 것을 알 수 있다 $(\mathrm{P}<0.05)$. 즉, 비 간부(3.8049)에 비해 간부(3.9887) 가 동료를 더욱 신뢰하고 있다는 것을 알 수 있다. 이러 한 이유는 간부들의 경우 계급이 상위직으로 갈수록 해 양경찰직에 대한 책임과 사명감이 비간부 보다 강하게 나타나기 때문인 것으로 보인다.

표 7. 간부와 비간부 유무에 따른 신뢰 수준 인식 차이

\begin{tabular}{|c|c|c|c|c|c|}
\hline \multicolumn{2}{|c|}{ 구분 } & \multirow{2}{*}{$\begin{array}{c}N \\
247\end{array}$} & \multirow{2}{*}{$\begin{array}{c}\text { 평균 } \\
3.2996\end{array}$} & \multirow{3}{*}{$\frac{t}{-1.451}$} & \multirow{3}{*}{$\begin{array}{c}\begin{array}{c}\text { 유의 } \\
\text { 확률 }\end{array} \\
0.148\end{array}$} \\
\hline \multirow{2}{*}{ 조직신뢰 } & 非간부 & & & & \\
\hline & 간부 & 53 & 3.4717 & & \\
\hline \multirow{2}{*}{ 상관신뢰 } & 非간부 & 247 & 3.6559 & \multirow{2}{*}{-1.835} & \multirow{2}{*}{0.068} \\
\hline & 간부 & 53 & 3.8679 & & \\
\hline \multirow{2}{*}{ 동료신뢰 } & 非간부 & 247 & 3.8049 & \multirow{2}{*}{-2.036} & \multirow{2}{*}{$\underline{0.043^{*}}$} \\
\hline & 간부 & 53 & 3.9887 & & \\
\hline
\end{tabular}

${ }^{*} p<0.05,{ }^{* *} p<0.01$ 


\section{4. 가설 검증}

본 연구에서 제시한 가설검증을 다음 [표 8]과 같이 요약해 보면, 우선, 해양경찰공무원의 경우 조직신뢰 요 인은 조직몰입에 강한 영향력을 미치고 있다는 것을 알 수 있었고, 다음으로 대인간 신뢰 요인 중에서는 동료 신뢰 요인이 상관신뢰 요인보다 상대적으로 더 많은 영 향력을 미치고 있다는 것을 알 수 있었다. 다음으로, 해 양경찰공무원의 인구사회학적 특성에 따른 신뢰요인 인식의 차이를 살펴보면, 비 간부에 비해 간부가 동료 를 더욱 신뢰하고 있다는 것을 알 수 있다.

\section{표 8. 가설검증 요약}

\begin{tabular}{|c|c|c|c|}
\hline \multicolumn{2}{|c|}{$\begin{array}{l}\text { 가설 } \\
\text { 번호 }\end{array}$} & 연구가설 & $\begin{array}{l}\text { 채택 } \\
\text { 여부 }\end{array}$ \\
\hline \multicolumn{2}{|c|}{ 대가설 | } & \multicolumn{2}{|l|}{$\begin{array}{l}\text { 해양경찰공무원의 신뢰 수준은 조직 } \\
\text { 몰입에 영향을 미칠 것이다. } \\
\end{array}$} \\
\hline \multirow{3}{*}{ 소가설 } & $\mid-1$ & $\begin{array}{l}\text { 조직 신뢰 수준은 조직 몰입에 영향 } \\
\text { 을 미칠 것이다. }\end{array}$ & 채택 \\
\hline & $1-2$ & $\begin{array}{l}\text { 상관 신뢰 수준은 조직 몰입에 } \\
\text { 영향을 미칠 것이다. }\end{array}$ & 채택 \\
\hline & $1-3$ & $\begin{array}{l}\text { 동료 신뢰 수준은 조직 몰입에 } \\
\text { 영향을 미칠 것이다. }\end{array}$ & 채택 \\
\hline \multicolumn{2}{|c|}{ 대가설 II } & \multicolumn{2}{|c|}{$\begin{array}{l}\text { 해양경찰공무원의 인구사회학적 특성에 } \\
\text { 따라 신뢰 요인 인식에 차이가 있을 것이다. }\end{array}$} \\
\hline \multirow{2}{*}{ 소가설 } & $\|-1$ & $\begin{array}{l}\text { 함정근무 유무에 따라 신뢰 수준 } \\
\text { 인식에 차이가 있을 것이다. }\end{array}$ & 기각 \\
\hline & $\|-2$ & $\begin{array}{l}\text { 간부와 비간부에 따라 신뢰 수준 } \\
\text { 인식에 차이가 있을 것이다. }\end{array}$ & $\begin{array}{l}\text { 일부 } \\
\text { 채택 }\end{array}$ \\
\hline
\end{tabular}

\section{V. 결론}

본 연구는 해양경찰조직에서 조직몰입의 필수적인 요건으로 조직 내에서의 신뢰가 축적되어야함을 역설 했다. 해양경찰조직은 해상에서 함정을 근무수단으로 하여 각종 해상치안을 담당하고 있기 때문에 해양경찰 공무원들의 경우 조직 내 신뢰의 요인들 별로 조직몰입 에 미치는 영향이 어떠한 양상을 띠는지에 대해 실증적 연구를 행한 결과 핵심내용은 다음과 같다.

해양경찰공무원의 경우 다른 선행연구물들에서 나타 난 결과와 마찬가지로 조직신뢰 요인은 조직몰입에 가 장 강한 영향력을 미치고 있다는 것을 알 수 있었고, 다
음으로 신뢰요인 중에서 동료신뢰 요인이 상관신뢰 요 인보다 상대적으로 더 많은 영향력을 미치고 있다는 것 을 알 수 있었다. 다음으로 해양경찰공무원의 인구사회 학적 특성에 따른 신뢰요인 인식의 차이를 살펴보면, 비 간부에 비해 간부가 동료를 더욱 신뢰하고 있다는 것을 알 수 있다.

따라서 해양 경찰의 경우 조직신뢰도와 동료에 대한 신뢰도를 향상시키는 조직 및 인사관리전략으로 조직 몰입도를 제고시켜야 한다는 시사점을 추론해 볼 수 있 다.

서울시정재개발연구원(2002)의 연구등에 의하면 조 직신뢰를 향상시키기 위해서는 첫째, 의사결정에 대한 참여를 보장하는 분권화, 둘째, 업무성과평가와 승진제 도의 공정성 등을 의미하는 인사의 공정성 제고, 셋째, 새로운 아이디어와 창의적인 사고를 중시하는 조직분 위기의 혁신이 필요함을 시사 하고 있다. 이러한 것들 은 결국 해양경찰의 인사 - 조직관리 정책입안시에도 해당되는 사항이 된다고 본다. 또한 동료에 대한 신뢰 도를 향상시키기 위해서는 해양경찰의 업무특성상 구 성원간의 상호협동과 유대가 전제가 되어야 하므로 동 료들간의 접촉기회나 각종 상호협동 문화창출이 필요 하다 할 것이다. 본 연구의 한계점으로 특히, 육상에서 근무하는 경찰공무원들과의 차이를 살펴보기 위한 비 교연구를 하지 못한점이다. 따라서 향후연구에서는 해 양경찰이 다른조직과 비교하여 조직내 신뢰요인별로 조직몰입에 미치는 영향에 있어 어떠한 차이가 있는 지 를 규명할 것이 필요로 되어진다.

\section{참 고 문 헌}

[1] 김호정, “신뢰와 조직몰입”, 한국행정학보, 제33 권, 제2호, pp.19-35, 1999.

[2] 박준철, 홍순복, “세무공무원의 의사결정참여, 상 사신뢰 성과피드백이 조직몰입과 직무생산성에 미치는 영향”, 인적자원관리연구, 제 14 권, 제 4 호, pp.171-183, 2007.

[3] Mayer, Roger C., Davis, James H., and 
Schoorman, F. David, "An Integrative Model of Organizational Trust," Academy of Management Review. Vol.20, No.3, pp.709-734, 1995.

[4] R. Kramer, Divergent Realities and Convergent Disappointments in The Hierarchic Relation: Trust and The Intuitive Auditor at Work. In R. M. Kramer. and T. R. Tyler(Eds), Trust in organizations: Frontiers of theory and research, pp.216-245, Thousand Oaks, CA: sage 1996.

[5] K. Griffin, The Contribution of Studies of Source Credibility to a Theory of Interpersonal Trust in The Communication Process. Psychological Bulletin. Vol.68, pp.104-120, 1967.

[6] L. W. Porter, R. M. Steers, R. T. Mowday, and P. V. Boulin, "Organizational Commitment, Job Satisfaction and Turnover among Psychiartic Technicians," Journal of Applied Psychology, Vol.50, pp.603-609, 1974.

[7] T. S. Bateman and S. Strasser, "Analysis of the Antecedents of Organizational Commitment," Academy of management Journal, Vol.27, No.1, pp.95-102, 1984.

[8] 조주은, "조직의 신뢰가 조직몰입과 서비스제공 행동에 미치는 영향," 관광연구저널, 제 19 권, 제 2 호, pp.261-273, 2005.

[9] McCauley, Dan P. and Kuhnert, Karl W, "A Theoretical Review and Empirical Investigation of Employee Trust in Management," Public Administration Quarterly, Vol.16, No.2, pp.265-285, 1992.

[10] 장석헌, 이강훈, "경찰조직문화가 조직몰입에 미 치는 영향에 관한 연구," 한국공안행정학회보, 제 26호, pp.43-64, 2007.

[11] 주재진, "경찰공무원의 입직동기가 조직몰입에 미치는 영향에 관한 연구," 한국경찰학회보, 제 10 권, 제2호, pp.223-243, 2008.
[12] 송병호, "경찰서장의 리더쉽이 경찰관의 조직몰 입에 미치는 영향에 관한 연구”, 한국경찰학회보, 제10호, pp.69-112, 2005.

[13] 이창한, "경찰관의 조직몰입에 영향을 미치는 요 인에 관한 연구," 한국경찰학회보, 제 12 호, pp.62-80, 2006.

[14] 김구, "경찰공무원의 직무스트레스요인이 직무 만족과 조직몰입에 미치는 영향”, 한국사회와 행 정연구, 제 16 권, 제 3 호, pp.59-87, 2005.

[15] J. D. Cook and T. D. Wall, "New Work Attitude Measure of Trust, Organizational Commitment and Personal Need Non-fulfilment," Journal of Occupational Psychology, Vol.53, pp.39-52, 1980.

[16] 김석용, "상사신뢰가 직무생산성과 조직몰입에 미치는 영향," 한국행정연구, 제 14 권, 제 4 호, pp.95-122, 2005.

[17] K. H. Roberts and C. A. O'Reilly, "Measuring Organizational Communication," Journal of Applied Psychology, Vol.59, No.3, pp.321-326, 1974.

[18] T. A. DeCotiis and T. P. Summers, "A Path Analysis of Model of the Antecedents \& Consequences of Organizational Commitment," Human Relations, Vol.40, pp.445-470, 1987.

[19] L. G. Hrebiniak and J. A. Alutto, "Personal and Role-Related Factors in the Development of Organizational Commitment," ASQ, Vol.17, pp.555-573, 1972.

[20] R. B. Blake and J. S. Mouton, Solving Costly Organizational Conflict. San Francisco: Jossey-Bass Publisher, 1984

[21] H. H. Tan and C. S. F. Tan, "Toward the Differentiation of Trust on Supervisor \& Trust in Organization," Genetic, Social, \& General Psychology Monographs, Vol.126, No.2, pp.241-260, 2000.

[22] 박철민, 김대원, "조직공정성이 상관신뢰와 공직 
몰입에 미치는 영향”, 한국행정학보, 제 35 권, 제 4 호, pp.353-373, 2001.

[23] 정찬수, “신뢰와 양상과 조직몰입에 관한 연구”, 연세대학교 대학원, 박사학위논문, 2005.

[24] 서울시정개발연구원, 서울시의 조직신뢰 향상방 안, 2002.

[25] P. M. Podsakoff, S. B. MacKenzie, R. H. Moorman and R. Fetter, "Transformational Leader Behaviors and Their Effects on Followers' Trust in Leaer, Satisfaction, and Prganizational Citizenship Behaviors," Leadership Quarterly. Vol.1, No.2, pp.107-142, 1990.

[26] 김호균, “조직신뢰, 상사신뢰와 조직효과성”, 행 정논총, 제46권, 제1호, pp.177-209, 2007.

[27] 황호영, 최영균, 김영구, 김웅, “동료에 대한 신 뢰가 팀성과에 미치는 영향에 관한 연구”, 산업경 제연구, 제18권 제4호, pp.1515-1539, 2005.

\section{저 자 소 개}

유 영 현(Yung-Hyun Yu)

정회원

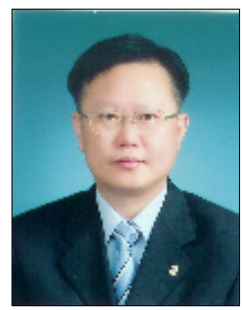

- 1988년 2월 : 원광대학교 대학원 - 2007년 2월 : 동국대학교대학원 - 2000년 현재 : 대불대학교 교 수

<관심분야> : 인사관리, 조직관리, 경찰행정 